\title{
46,XX Male - Testicular Disorder of Sexual Differentiation (DSD): hormonal, molecular and cytogenetic studies
}

\author{
Homem 46,XX (DSD testicular): estudos \\ hormonal, molecular e citogenético
}

Cresio Alves', Zilda Braid', Fernanda Borchers Coeli², Maricilda Palandi de Mello²

\section{SUMMARY}

The XX male syndrome - Testicular Disorder of Sexual Differentiation (DSD) is a rare condition characterized by a spectrum of clinical presentations, ranging from ambiguous to normal male genitalia. We report hormonal, molecular and cytogenetic evaluations of a boy presenting with this syndrome. Examination of the genitalia at age of 16 months, showed: penis of $3.5 \mathrm{~cm}$, proximal hypospadia and scrotal testes. Pelvic ultrasound did not demonstrate Mullerian duct structures. Karyotype was $46, \mathrm{XX}$. Gonadotrophin stimulation test yielded insufficient testosterone production. Gonadal biopsy showed seminiferous tubules without evidence of Leydig cells. Molecular studies revealed that $S R Y$ and TSPY genes and also DYZ3 sequences were absent. In addition, the lack of deletions or duplications of SOX9, NR5A1, WNT4 and NROB1 regions was verified. The infant was heterozygous for all microsatellites at the $9 \mathrm{p}$ region, including DMRT1 gene, investigated. Only $10 \%$ of the patients are $S R Y$-negative and usually they have ambiguous genitalia, as the aforementioned patient. The incomplete masculinization suggests gain of function mutation in one or more genes downstream to SRY gene. Arq Bras Endocrinol Metab. 2010;54(8):685-9

\section{SUMÁRIO}

A síndrome do homem $X X$ é uma condição rara na qual o fenótipo da genitália externa pode variar de uma genitália ambígua até uma genitália masculina normal. Este estudo tem por objetivo relatar a avaliação hormonal, molecular e citogenética de um menino com essa síndrome. 0 exame da genitália externa na idade de 16 meses mostrava: pênis medindo $3,5 \mathrm{~cm}$, hipospadia proximal e testículos tópicos. A ultrassonografia pélvica não visualizou estruturas mullerianas. Cariótipo foi $46, X X$. A testosterona sérica não se elevou após o teste de estímulo com gonadotrofina. Biópsias gonadais mostraram túbulos seminíferos, sem evidência de células de Leydig. Estudos moleculares revelaram ausência dos genes SRY, TSPY e DYZ3, bem como ausência de deleção ou duplicação das regiões SOX9, NR5A1, WNT4 e NROB1. A criança era heterozigótica para todos os microssatélites da região 9p, incluindo o gene DMRT1. Apenas 10\% dos pacientes com a síndrome do homem 46,XX são SRY-negativos. Nesses casos, a genitália geralmente é ambígua, como corroborado pelo paciente do presente relato. A masculinização incompleta sugere ganho de mutação funcional em um ou mais genes a jusante do gene SRY. Arq Bras Endocrinol Metab. 2010;54(8):685-9

${ }^{1}$ Pediatric Endocrinology Service Hospital Universitário Professor Edgard Santos, Faculty of Medicine, Universidade Federal da Bahia (UFBA), Salvador, BA, Brazil ${ }^{2}$ Centro de Biologia Molecular e Engenharia Genética, Universidade Estadual de Campinas (Unicamp), Campinas, SP, Brazil
Correspondence to: Cresio Alves

Rua Plínio Moscoso, 222/601 40157-190 - Salvador, BA, Brazil cresio.alves@uol.com.br

Received on Jun/4/2010 Accepted on Sept/12/2010

\section{INTRODUCTION}

$\mathrm{T}$ he XX male syndrome (OMIM ID \#400045), now termed Testicular DSD (Testicular Disorder of Sexual Differentiation), was first described by La Chapelle and cols. in 1964 (1). It is a rare condition, with a frequency of 1:20,000-25,000 male newborns (1-3). It is characterized by a male phenotype with $46, \mathrm{XX}$ karyo- type (1-3). The SRY gene (sex-determining region on the $\mathrm{Y}$ ), which is located in the $\mathrm{Y}$ chromosome, plays an important role in the process of sex determination $(4,5)$. On basis of the analysis and detection of $S R Y$ gene, 46, XX male patients can be clinically divided into $S R Y$-positive and the SRY-negative groups $(6,7)$. SRYpositive individuals usually have normal male genitalia, 
small azoospermic testes and hypergonadotropic hypogonadism (8), and most carry the $S R \Upsilon$ gene translocated to the X chromosome during paternal meiosis $(7,9)$; however, $S R \Upsilon$ autosomal translocations have also been reported in some XX males (10-12). The diagnosis of $S R \Upsilon$-positive patients is usually achieved in adulthood during infertility investigation (3). The group of $S R Y$ negative (OMIM ID 278850) includes patients with Ovotesticular-DSD, which is characterized by the presence of both testicular and ovarian tissue in the gonads of the same individual $(13,14)$, and Testicular-DSD characterized by a full development of both gonads as testes without any evidence of ovarian tissue (2). The occurrence of both Ovotesticular and Testicular-DSD in families, especially in identical twins, indicates them as different manifestations of the same disorder of gonadal development (15-17). In the absence of SRY gene, the up-regulation or super-expression of some members of SOX family (Sry-related HMG-box) have been proposed as involved in XX male etiology (1820). The diagnosis of $S R Y$-negative testicular-DSD can be done in childhood upon investigation of ambiguous genitalia and gynecomastia.

The aim of this study was to analyze the case of a boy with XX male syndrome, emphasizing its hormonal, molecular and cytogenetic aspects.

\section{CASE REPORT}

A 16-month-old infant was referred to endocrine evaluation in our service. The mother reported that fetal sonograms between the $3^{\text {rd }}-6^{\text {th }}$ months of gestational age were compatible with a female fetus, while at the $7^{\text {th }}$ month the diagnosis was compatible with a male fetus with hypospadia. There were absence of endocrinopathies and hormonal exposure during pregnancy, no history of genetic syndromes, ambiguous genitalia or precocious neonatal death in the family. Parents are not consanguineous and his 5 years-old sister is healthy. On physical examination: weight: $10.2 \mathrm{~kg}$ (P. 10 - P. $25)$, length: $73.5 \mathrm{~cm}(<$ P. 5\%). The penile length was $3.5 \mathrm{~cm}$ with a proximal hypospadia, both testes were normally located (with a more hypoplastic left testicle) and absent pubarche. Karyotype with G band: 46,XX. Neonatal screening, including 17-hydroxyprogesterone evaluation was normal. Pelvic ultrasound: no evidence of Mullerian duct structures. Gonadal biopsy: seminiferous tubules lined by small cuboidal cells, without evidence of Leydig cells.

\section{MATERIALS AND METHODS}

The hormonal studies were performed with the human chorionic gonadotrophin stimulation tests (beta-hCG) measuring total testosterone, before and after the administration of three doses of beta-hCG $(4,500 \mathrm{IU}$, intramuscularly, every other day).

Molecular studies were performed after DNA extraction from peripheral blood, that followed standard techniques (21). Y-chromosome sequence analysis was conducted by PCR and nested-PCR. SRY gene was amplified with primers depicted in table 1 , which also describes those primers used in the first and in the second rounds of nested-PCR for the TSPY gene and for the Y-centromeric region DYZ3. After PCR amplification, reaction products ( $10 \mu \mathrm{l}$ ) were submitted to $2 \%$ agarose gel electrophoresis with a molecular weight marker and stained with ethidium bromide. Each PCR reaction contained normal female and male controls. Nested-PCR experiments contained also a template-free sample. Haploinsuficiency of DMRTI gene was evaluated with microsatellites mapping within the criptical interval 9p24.3 according to Calvari and cols. (22), Guioli and cols. (23) and Veitia and cols. (24) (Table 2). MLPA assay was performed using SALSA MLPA P185 Intersex probemix (MRC-Holland) following provider instructions.

Table 1. Primer sequences for PCR and nested-PCR of the $Y$ chromosome

\begin{tabular}{|c|c|c|c|}
\hline Gene & Forward Primer 5' $\rightarrow$ 3' & Reverse Primer 5' $\rightarrow 3^{\prime}$ & Size (bp) \\
\hline SRY & $\begin{array}{l}\text { CAT TGT CGA CCA GTG TGT } \\
\text { TGA AAC GGG AGA AAA CA }\end{array}$ & $\begin{array}{c}\text { CAT TGT CGA CGT ACA ACC CTG TTG } \\
\text { TCC AGT TGC }\end{array}$ & 380 \\
\hline TSPY JA 56/52 & CAT GAC ATA ATG GCG GAG & CGA TAG GCC TCC ACT TCA TA & 1300 \\
\hline TSPY JA 35/30* & CCC CAC CTA GAC CGC AGA GG & GGG AAG AAG GCC TAA GAG CAC C & 608 \\
\hline DYZ3 A/B & TGA AAA CTA CAC AG- AAG CTG & ACA CAT CAC AAA GAA CTA TG & 1100 \\
\hline DYZ3 G/H* & AGC CTT TTG TGG CCT ACG & ATC CTC CTG GAG ATA CCA & 330 \\
\hline
\end{tabular}

* Internal primers for nested-PCR. 
Table 2. Primer sequences utilized for the $9 p$ microsatellite studies

\begin{tabular}{lcccc}
\hline Marker & Size $\mathbf{( p b )}$ & Primer Sense & Primer Antissense & \% \\
\hline D9S1779 & $120-144$ & CCCTGCCAGGTGTGCATCTG & TCAGGCTCCCTCGTGGCTCT & 63 \\
D9S1858 & $236-248$ & TGCACTGTCCTGCCAAG & CCCAGACTCAGATTTCCCA & 58 \\
D9S143 & 111 & CCAAAAATGATGACTACATCC & GCAACAACAAAAATGAACACT & 54 \\
D9S1813 & $226-264$ & GGGCCTGGCACTTAATAC & AATGGCCTAAATAAAACCTGG & 83 \\
D9S54 & $110-121$ & GAAAGTCCAGAACTAAGTAG & TGTGGATAGGTATATATAGC & $?$ \\
\hline
\end{tabular}

$\%=$ percentage of heterozygous estimated for this locus.

Each MLPA reaction was analyzed on an ABI 310 Genetic Analyzer (ABI PRISM/PE Biosystems, Foster City, CA, USA) and results were evaluated using Genescan and Genotyper softwares (Applied Biosystems, Foster City, CA, USA). The probemix included in the MLPA kit contains probes for $S O X 9$ gene and its flanking region at $17 \mathrm{q} 24.3, \mathrm{NR} 5 \mathrm{Al}$ gene $(\mathrm{SF}-1)$ at $9 \mathrm{q} 33$, WNT4 (1p36.12), NROB1 gene (DAX-1) at Xp21.2 and, also, control probes mapping within other regions on $\mathrm{X}$ and $\mathrm{Y}$ chromosomes. Data were analyzed using free Coffalyser MLPA data analysis software available in the provider website (www.mrc-holland.com). Data were normalized with results of five control individuals and with internal controls (reference probes). Normalized relative values ranging within a confidence interval of 0.8 to 1.3 , which was established by control data variations, corresponded to two gene copies in the genotype, whereas values below 0.8 and above 1.3 would correspond to deletion (one gene copy) and duplication (three gene copies), respectively.

This paper was submitted to the Institutional Review Board of our Institution, which approved its ethical aspects.

\section{RESULTS}

The hormonal studies yielded low serum levels of free testosterone before and after the beta-hCG stimulation test suggesting a deficient testicular production (Table 3 ).

Table 3. Human chorionic gonadotrophin stimulation test at the chronological age of 16 months

\begin{tabular}{lccc}
\hline \multirow{2}{*}{ Time } & \multicolumn{3}{c}{ Hormonal evaluation } \\
\cline { 2 - 4 } & LH & FSH & Total testosterone \\
\hline Baseline & $<0,07 \mathrm{UI} / \mathrm{mL}$ \\
$(\mathrm{normal}<14 \mathrm{UI} / \mathrm{L})$ & $\begin{array}{c}<0,3 \mathrm{UI} / \mathrm{mL} \\
(\text { normal }<10 \mathrm{UI} / \mathrm{L})\end{array}$ & $\begin{array}{c}12 \mathrm{ng} / \mathrm{dL} \\
(\text { normal }<40 \mathrm{ng} / \mathrm{dL})\end{array}$ \\
Post- & & & $40 \mathrm{ng} / \mathrm{dL}$ \\
-stimulation & & & $($ normal $>150 \mathrm{ng} / \mathrm{dL})$ \\
\hline
\end{tabular}

FSH: follicle-stimulating hormone; $\mathrm{LH}$ : luteinizing hormone.

Molecular analyses demonstrated absence of both SRY and TSPY genes and also Y-centromeric DYZ3 sequence indicating absence of Y-chromosome-derived sequences in the genotype. The infant was heterozygous for all $9 \mathrm{p}$ microsatellites indicating haplosufficiency for DMRT1 gene. Deletions or duplications of genes involved in sex differentiation processes were investigated by MLPA analysis. Normal copy number for all genes can be observed in figure 1. Absence of Y-chromosome

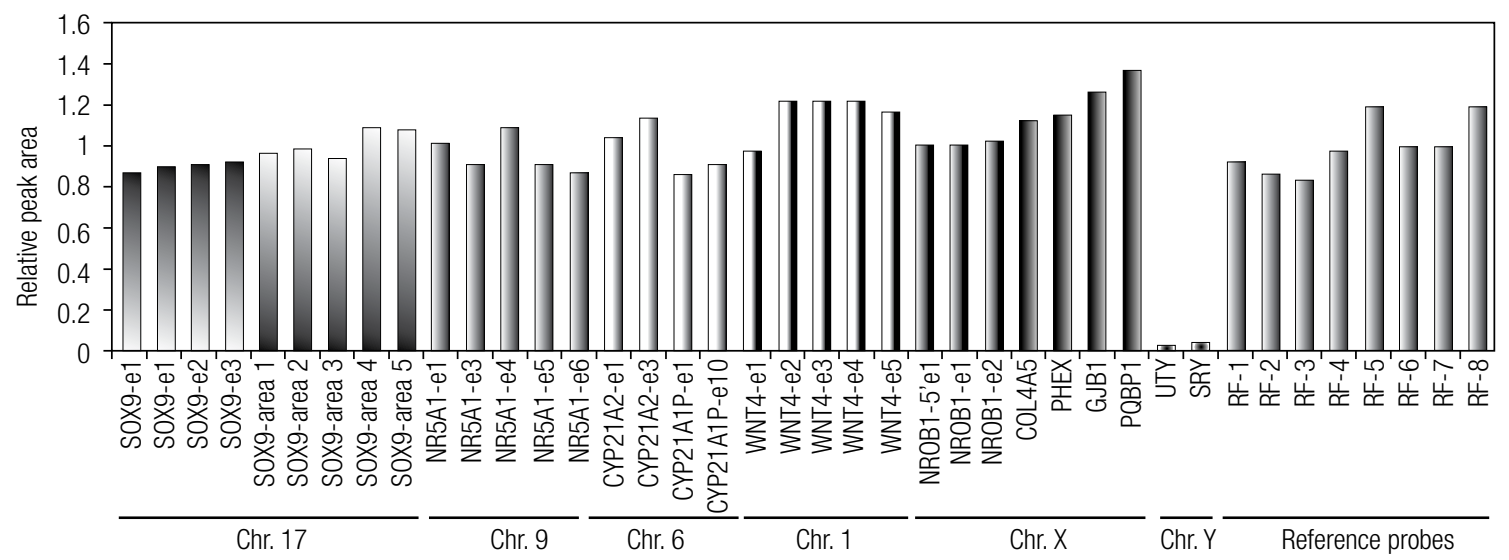

Figure 1. MLPA analysis. Integrated and normalized MLPA data for genes: SOX9(17q24.3), NR5A1 (9p33), WNT4(1p36.12) and NROB1 (Xp21.2). Genes or gene regions are indicated below each bar in the graphic; $\mathrm{e}=$ exon. Chromosome regions are delimitated by black horizontal bars. Absence of signals for both UTY region and $S R Y$ gene probes on the Y chromosome is observed. The height of vertical bars corresponds to integrated and normalized peak areas obtained in capillary electrophoresis; values between 0.8 and 1.3 indicate two copies of the fragment. 
probe signals can also be noted confirming PCR assays. Therefore, MLPA did not show any copy number variation for either SOX9, NR5AI (SF-1), WNT4 or DAX-1, which is coded by NROBI gene.

\section{DISCUSSION}

About $90 \%$ of $46, \mathrm{XX}$ (testicular DSD) men are SRY gene carriers. In most cases this gene is translocated to the short arm-end of the paternal X chromosome $(1,3)$. Therefore the mechanism generating this syndrome in SRY carriers involves mainly a mistake in the cross-over between pseudoautosomal regions of sexual chromosomes during the paternal meiosis $(10,18)$. However, $10 \%$ of the patients are $S R Y$-negative $(1,3)$. Molecular analysis in our patient showed absence of $S R \Upsilon$, which is an unusual form of the XX male syndrome.

It has been considered that, in the absence of a functional SRY protein, male phenotype can also be induced in 46,XX individuals by excessive or absent actions of other determinants within the sexual differentiation cascade such as SOX9, DAX-1, Ad4BP/SF-1, WT1, GATA4, WNT4, FGF9 and RSPOl $(10,18)$. In the patient described here, there was no evidence for SOX9, SF-1, WNT4 and DAX-1 duplications or deletions that were investigated by MLPA technique.

In general, 46,XX male presents with three phenotypes: normal internal and external genitalia; ambiguous genitalia; and, ovotesticular DSD (1-3). All are characterized by infertility caused by absence of the region AZF present in the long arm of the $\mathrm{Y}$ chromosome ( 1 3 ). In the classical presentation, 46,XX males are found with normal penile length, infertility and presence of Wolff duct structures without Mullerian duct structures (18). There is a higher prevalence of microrchidism and gynecomastia and a trend to female pubic hair distribution, with decreased facial hair $(1,10)$. Short stature can occur due to absence of either pubertal spurt dependent on testosterone or Y-chromosome genes related to specific growth forms.

Most SRY-positive patients have normal external genitalia, whereas SRY-negative patients are found within a large spectrum of masculinization ranging from ambiguous to normal genitalia $(1,3)$. The diagnosis of the patient reported here was performed during childhood due to ambiguous genitalia. Ovotesticular DSD, an important differential diagnosis, was ruled out in the patient after gonadal biopsy. During puberty, testosterone levels are normal evolving, in adulthood, to hypergonadotrophic hypogonadism $(6,7,10,15,18)$. Some authors evidenced a deficient testosterone production after $\beta$-hCG stimulation test; whereas, others reported a normal testosterone production by the Leydig cells, although not ruling out the possibility of a testosterone deficiency during adulthood $(3,10)$.

In conclusion, the SRY-negative XX male incomplete masculinization in this case cannot be attributed to SOX9, SF-1, WNT4 and DAX-1 duplications or deletions, however, gain of function mutations in one or more genes downstream the SRY gene pathway or a loss of function in some gene associated with the inhibition of male development should be considered for further investigation.

Disclosure: no potential conflict of interest relevant to this article was reported.

\section{REFERENCES}

1. Vorona E, Zitsmann M, Gromoll J, Schüring N, Nieschlag E. Clinical, endocrinological, and epigenetic features of the $46, X X$ male syndrome, compared with 47,XXY Klinefelter patients. J Clin Endocrinol Metab. 2007;92:3458-65.

2. Rajender S, Vutukuri R, Gupta NJ, Chakravarty B, Singh L, Thangaraj K. SRY-negative 46,XX male with normal genitals, complete masculinization and infertility. Mol Hum Reprod. 2006;5:341-6.

3. Ergun-Longmire B, Vinci G, Alonso L, Matthew S, Tansi S, Lin-Su $\mathrm{K}$, et al. Clinical, hormonal and cytogenetic evaluation of $46, \mathrm{XX}$ male and review of the literature. J Pediatr Endocrinol Metab. 2005;18(8):739-48.

4. Berta P, Hawkins JR, Sinclair AH, Taylor A, Griffiths BL, Goodfellow PN, et al. Genetic evidence equating SRY and the testisdetermining factor. Nature. 1990;348(6300):448-50.

5. Koopman P, Münsterberg A, Capel B, Vivian N, Lovell-Badge R. Expression of a candidate sex-determining gene during mouse testis differentiation. Nature. 1990;348(6300):450-2.

6. Kim JW, Bak CW, Chin MU, Cha DH, Yoon TK, Shim SH. SRY-negative $46, X X$ infertile male with Leydig cell hyperplasia: clinical, cytogenetic, and molecular analysis and review of the literature. Fertil Steril. 2010;94(2):753.e5-9.

7. Wang T, Liu JH, Yang J, Chen J, Ye ZO. 46, XX male sex reversal syndrome: a case report and review of the genetic basis. Andrologia. 2009;41(1):59-62.

8. de la Chapelle A. The etiology of maleness in XX men. Hum Genet. 1981;58(1):105-16.

9. Fechner PY, Marcantonio SM, Jaswaney V, Stetten G, Goodfellow $\mathrm{PN}$, Migeon $\mathrm{CJ}$, et al. The role of the sex-determining region $Y$ gene in the etiology of $46, X X$ maleness. J Clin Endocrinol Metab. 1993;76(3):690-5.

10. Dauwerse JG, Hansson KBM, Brouwers AAM, Peters DJM, Breuning $\mathrm{MH}$. An $\mathrm{XX}$ male with the sex-determining region $Y$ gene inserted in the long arm of cromossome 16. Fertil Steril.2006:86:463.e2-e5.

11. Chien SC, LiYC, Ho M, Hsu PC, Teng RH, Lin WD, et al. Rare rearrangements: a "jumping satellite" in one family and autosomal location of the SRY gene in an XX male. Am J Med Genet A. 2009;149A(12):2775-81. 
12. Queralt R, Madrigal I, Vallecillos MA, Morales C, Ballescá JL, Oliva $R$, et al. Atypical $X X$ male with the SRY gene located at the long arm of chromosome 1 and a 1qter microdeletion. Am J Med Genet A. 2008;146A(10):1335-40.

13. Parada-Bustamante $A$, Ríos $R$, Ebensperger $M$, Lardone MC, Piottante A, Castro A. 46,XX/SRY-negative true hermaphrodite. Fertil Steril. 2010;94(6):2330.13-6.

14. Berger-Zaslav AL, Mehta L, Jacob J, MercadoT, Gadi I,Tepperberg $\mathrm{JH}$, et al. Ovotesticular disorder of sexual development (true hermaphroditism). Urology. 2009;73(2):293-6.

15. Maciel-Guerra AT, de Mello MP, Coeli FB, Ribeiro ML, Miranda $M L$, Marques-de-Faria $A P$, et al. $X X$ Maleness and $X X$ true hermaphroditism in SRY-negative monozygotic twins: additional evidence for a common origin. J Clin Endocrinol Metab. 2008;93(2):339-43.

16. Ramos ES, Moreira-Filho CA, Vicente YA, Llorach-Velludo MA, Tucci S, Duarte $\mathrm{MH}$, et al. SRY-negative true hermaphrodites and an $\mathrm{XX}$ male in two generations of the same family. Hum Genet. 1996;97:596-8.

17. Zenteno JC, Lopez M, Vera C, Mndez JP, Kofman-Alfaro S. Two SRY-negative $X X$ male brothers without genital ambiguity. Hum Genet. 1997;100:606-10.

18. Kojima Y, Hayashi Y, Mizuno K, Sasaki S, Fukui Y, Koopman P, et al. Up-regulation of SOX9 in human sex-determining region on the $Y$ chromosome (SRY)-negative $X X$ males. Clin Endocrinol. 2008:68(5):791-9.

19. Refai O, Friedman A, Terry L, Jewett T, Pearlman A, Perle MA, et al. De novo 12;17 translocation upstream of SOX9 resulting in $46, X X$ testicular disorder of sex development. Am J Med Genet A. 2010;152A(2):422-6.

20. Polanco JC, Wilhelm D, DavidsonTL, Knight D, Koopman P. Sox10 gain-of-function causes $X X$ sex reversal in mice: implications for human 22q-linked disorders of sex development. Hum Mol Genet. 2010;19(3):506-16.

21. Sambrook J, Fristsch EF, Maniatis TE. Molecular cloning: a laboratory manual. Cold Spring Harbour Laboratory, Press. NewYork: Cold Spring Harbour, 1989.

22. Calvari V, Bertini V, De Grandi A, Peverali G, Zuffardi O, et al. A new submicroscopic deletion that refines the $9 p$ region for sex reversal. Genomics. 2000:65(3):203-12.

23. Guioli S, Schmitt K, Critcher R, Bouzyk M, Spurr NK, OgataT, et al. Molecular analysis of $9 p$ deletions associated with $X Y$ sex reversal: refining the localization of a sex-determining gene to the tip of the chromosome. Am J Hum Genet. 1998:63(3):905-8.

24. Veitia RA, Nunes M, Quintana-Murci L, Rappaport R, Thibaud $E$, Jaubert $F$, et al. Swyer syndrome and 46,XY partial gonadal dysgenesis associated with $9 p$ deletions in the absence of monosomy-9p syndrome. Am J Hum Genet. 1998:63(3):901-5. 